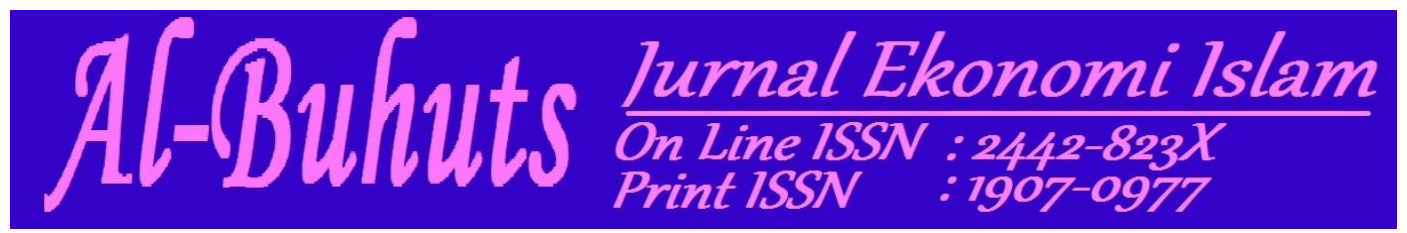

Volume. 12, Nomor 1, Juni 2016

\title{
Potensi, Peluang, Dan Tantangan Perdagangan Antara Indonesia Dengan Negara-Negara Di Kawasan Timur Tengah
}

\section{Oleh}

\section{Sudirman}

Fakultas Ekonomi dan Bisnis Islam IAIN Sultan Amai Gorontalo Email: yudih65@yahoo.co.id

\begin{abstract}
ABSTRAK
Penelitian ini bertujuan untuk mengkaji potensi, peluang, dan tantagan perdagangan antara Indonesia dengan negara-negara di kawasan timur tengah. Penelitian ini adalah penelitian kualitatif dengan menggunakan metode deskriptif. Data yang digunkan adalah data sekunder yang diambil dari lembaga-lembaga terkait, antara lain: Disperindag, Kadin, Badan Pusat Statistik, dan dari dokumen-dokumen yang terkait lainnya. Pada penelitian ini ditemukan berbagai potensi, peluang, dan tantangan perdagangan antara Indonesia dengan Negaranegara di kawasan timur tengah, yaitu: 1) potensi, antara lain: produkproduk yang dihasilkan di Indonesia cenderung berbeda dengan produk yang dihasilkan di negara-negara kawasan timur tengah, Pertumbuhan ekonomi di negara-negara timur tengah relatif stabil. Indonesia memilikin komoditi ekspor yang cukup beragam, daya saing produk Indonesia cukup tinggi, dan pertumbuhan modal asing di negara-negara timur tengah cenderung meningkat. 2) peluang, antara lain: Adanya perubahan kebijakan ekonomi di yang berorientasi pada ekonomi pasar, hubungan diplomasi bilateral antara Indonesia dengan negara-negara di timur tengah telah terjalin dengan baik, persamaan keyakinan, adanya wacana akan dilakukannya perdangan perdagangan bebas antara Indonesia dengan Maroko dan Turki. 3) tantangan, antara lain: Jarak yang panjang, tarif bea masuk yang tinggi, iklim politik yang kurang stabil, terbtasnya dukungan dari sektor lembaga keuangan, belum tersedianya lembaga sertifikasi halal yang mendapatkan legitimasi secara internasional.

Kata Kunci: Potensi, Peluang, dan Tantangan.
\end{abstract}




\section{ABSRACT}

This study aims to assess the potential, opportunities, and challenge of trade between Indonesia and countries in the middle east. It is qualitative research by using descriptive method. The data is used mainly secondary data, it drawn from relevant institutions, among others: industry and trade, chamber of commerce, the Central Bureau of Statistics, and of the documents related. This study found a variety of potentials, opportunities, and challenges of trade between Indonesia and countries in the middle east, namely: 1) the potential, among other things: the products produced in Indonesia tend to be different from the product produced in the countries middle east region countries, economic growth in the countries of the Middle east are relatively stable. Indonesia has export commodity that was diverse, the competitiveness of Indonesian products is quite high, and the growth of foreign capital in the countries of the Middle East are likely to increase. 2) opportunities, among others:

A change in economic policy-oriented market economy, relations bilateral diplomacy between Indonesia and countries in middle east has been good, the equation beliefs, it discourse will do the trade in free trade Indonesia between Morocco and Turkey. 3) challenges, among others: Long distance, tariffs are high, less stable political climate, limited support of the financial institutions sector, unavailability of halal certification bodies are gaining international legitimacy.

Keywords : Potential, Opportunities, and Challenges.

\section{A. Latar Belakang}

Perdagangan internasional telah berlangsung dalam jangka waktu yang sudah cukup lama. Pada saat itu, sistem perdagangan dilakukan dengan cara sistem barter, yaitu melakukan pertukaran barang dengan barang, antara suatu negara dengan negara yang lainnya. Sejak akhir abad ke 20 hubungan perdagangan antar negara terus berkembang. Kondisi tersebut, ditandai dengan semakin meningkatnya aliran barang

\footnotetext{
${ }^{1}$ Rina Oktaviani, Jurnal Agro Ekonomi, Volume 26 No. 2 Oktober 2008, h. 167-189.
} 
dan jasa antar negara. Seiring dengan berjalannya waktu, perekonomian dunia terus berkembang dengan sedemikian pesatnya, sehingga menyebabkan integrasi dan dinamika perdagangan antar negara kian meningkat.

Kondisi perekonomian yang kian berkembang, akan menimbulkan berbagai dampak terhadap perekonomian di berbagai negara, baik dampak positif maupun dampak negatif. Dampak positifnya, negara-negara tersebut akan mendapatkan banyak manfaat dari aktivitas perdagangan internasional. Sedangkan dampak negatifnya, negara bersangkutan akan cenderung dirugikan apabila melakukan perdagangan internasional. Perdagangan internasional akan berjalan dengan baik apabila di antara negara-negara yang melakukan hubungan perdagangan akan mendapatkan keuntungan yang memadai. Selain itu, perdagangan antar negara dapat berlangsung dengan baik apabila oleh masing-masing negara yang sedang berdagang terjadi saling keterbukaan.

Tujuan dari perdagangan internasional adalah untuk mendapatkan keuntungan yang semaksimal mungkin. Walaupun demikian, terkadang suatu negara tidak mendapatkan keuntungan yang memadai apabila mereka melakukan perdagangan dengan negara-negara yang lebih maju, karena daya saing oleh negara-negara tersebut lebih tinggi jika dibandingkan dengan daya saing negara-negara yang sedang berkembang, sehingga manfaat yang akan diterima oleh negara-negara maju juga akan lebih banyak jika dibandingkan dengan manfaat yang akan diterima oleh negara yang sedang berkembang. Untuk mengurangi berbagai potensi dampak negatif perdagangan Internasional, maka suatu negara sangat penting untuk memiliki strategi khusus dalam menghadapi perdagangan internasional agar mampu bertahan di tingkat persaingan internasional.

Strategi diverifikasi pasar merupakan salah satu cara yang cukup efektif untuk mengurangi dominasi suatu negara terhadap pasar dalam negeri, sehingga mengurangi pula tingkat ketergantungan pasar terhadap negara-negara tertentu, seperti yang dialami Indonesia saat ini, orientasi pasarnya didominasi oleh empat negara, yaitu, Amerika, Cina, Jepang, dan Singapura, sehingga setiap terjadi gejolak ekonomi oleh negaranegara tersebut, mengakibatkan pula ekonomi Indonesia ikut terkena dampaknya. Oleh karenanya, meminimalisir dampak negatif dari kondisi tersebut, maka sebaiknya pemerintah Indonesia mengembangkan wilayah pasarnya dengan melakukan ekspansi pasar ke negara-negara lainnya, termasuk di negara-negara kawasan Timur Tengah, meliputi Arab Saudi, 
Turki, Maroko, Tunisia, dan Afrika yang saat ini memiliki potensi yang cukup baik.

Pada era perdagangan bebas, jarak dianggap bukan sebagai faktor penghambat ekspansi pasar. Semua negara dapat dipertimbangkan sebagai pasar yang penting bagi eksportir suatu negara, termasuk Indonesia. Dalam hal ini, Turki dipandang sebagai pintu gerbang perdagangan dan investasi, dikarenakan kedekatannya dengan pasar utama, seperti Eropa, Timur Tengah dan Kaukasus. Saat ini, Turki telah menandatangani FTA dengan European Free Trade Association (EFTA), Mesir, Israel, Macedonia, Kroasia, Bosnia-Herzegovina, Maroko, Tunisia, Otoritas Palestina, da Siria. Selain itu, Turki memiliki potensi pasar dengan jumlah penduduk lebih dari 70 juta jiwa. Di samping itu, Turki juga mempunyai sistem perdagangan yang sangat liberal, dan lingkungan investasi yang difasilitasi.

Kawasan Timur Tengah merupakan salah satu jalur perdagangan yang memiliki potensi yang cukup baik, sehingga harus digarap lebih serius. Saat ini, pertumbuhan nilai ekspor Indonesia ke negara-negara ini terus meningkat, yaitu pada tahun 2014 pasar ekspor di kawasan ini naik sebesar 43 persen. Begitu pula dengan Indonesia, nilai ekspor Indonesia ke Uni Emirat Arab (UAE) meningkat sebesar 252,02 persen. Salah satu produk unggulan Indonesia adalah produk alat kesehatan khusus untuk produk peralatan kesehatan, nilai ekspor Indonesia ke UEA meningkat sebesar 31,79 persen atau sebesar sebesar USD 3,57 miliar pada periode Januari-Oktober tahun 2014. UEA merupakan pintu masuk ekspor bagi kawasan Timur Tengah. Negara-negara di sekitarnya membutuhkan berbagai produk peralatan kesehatan, terutama negara-negara yang tengah terlibat konflik. ${ }^{3}$ Perkembangan perdagangan Indonesia ke negara-negara kawasan Timur Tengah dapat dilihat pada tabel 1.1 berikut ini:

\section{Tabel: 1.1 Neraca Perdaganan antara Indonesia dengan Negara- Negara di Kawasan Timur Tengah.}

\footnotetext{
${ }^{2}$ Buletin Ilmiah Litbang Perdagangan, Vol. 5 No. 1 Juli 2011, h. 63.

${ }^{3}$ Buletin Ilmiah Litbang Perdagangan, Vol. 5 No. 1 Juli 2011, h. 63.

${ }^{4}$ Buletin Ilmiah Litbang Perdagangan, Vol. 5 No. 1 Juli 2011, h. 64.
} 
Volume. 12, Nomor 1, Juni 2016 Hataman 60-80
Potensi, Peluang, Dan Tantangan Perdagangan Antara Indonesia Dengan Negara-Negara Dí Kawasan Timur Tengah

\begin{tabular}{|c|c|c|c|c|c|c|c|c|c|}
\hline \multirow{2}{*}{$\begin{array}{l}\text { TOTAL } \\
\text { PERDAGAN } \\
\text { G/ } \\
\text { NEGARA }\end{array}$} & \multirow{2}{*}{2010} & \multirow{2}{*}{2011} & \multirow{2}{*}{2012} & \multirow{2}{*}{2013} & \multirow{2}{*}{2014} & \multirow{2}{*}{$\begin{array}{l}\text { Trend } \\
(\%) \\
2010- \\
2014\end{array}$} & \multicolumn{2}{|l|}{ Jan-Mar } & \multirow{2}{*}{$\begin{array}{l}\text { Perub. } \\
(\%) \\
2015 / 2 \\
014\end{array}$} \\
\hline & & & & & & & 2014 & 2015 & \\
\hline ALJAZAIR & $420.682,2$ & $489.051,6$ & $519.151,9$ & $\mid \begin{array}{l}619.779 \\
4\end{array}$ & $\mid \begin{array}{l}478.368, \\
0\end{array}$ & 5,06 & $\begin{array}{l}265.376, \\
9\end{array}$ & $\begin{array}{l}74.295 \\
, 5\end{array}$ & $-72,00$ \\
\hline $\begin{array}{l}\text { ARAB } \\
\text { SAUDI }\end{array}$ & $5.528 .136,3$ & $\begin{array}{l}6.856 .719, \\
0\end{array}$ & $\mid \begin{array}{l}6.973 .852, \\
1\end{array}$ & $\mid \begin{array}{l}8.260 .44 \\
1,1\end{array}$ & \begin{tabular}{|l}
8.672 .54 \\
9,1
\end{tabular} & 11,48 & $\begin{array}{l}1.904 .33 \\
4,0\end{array}$ & $\begin{array}{l}1.406 . \\
926,5\end{array}$ & $-26,12$ \\
\hline BAHRAIN & $167.550,3$ & $124.451,9$ & $106.598,2$ & $\begin{array}{l}116.098 \\
6\end{array}$ & $\begin{array}{l}219.593, \\
0\end{array}$ & 4,83 & $42.364,4$ & $\begin{array}{l}19.568 \\
, 4\end{array}$ & $-53,81$ \\
\hline IRAK & $52.836,8$ & $154.868,8$ & $44.993,4$ & $45.519,2$ & $72.659,1$ & $-5,70$ & $20.408,0$ & $\begin{array}{l}15.665 \\
, 3\end{array}$ & $-23,24$ \\
\hline KUWAIT & $1.470 .549,0$ & $\begin{array}{l}1.528 .604, \\
9\end{array}$ & $\begin{array}{l}2.311 .314 \\
5\end{array}$ & $\begin{array}{l}1.584 .33 \\
9,0\end{array}$ & $\begin{array}{l}1.632 .59 \\
3,3\end{array}$ & 2,48 & $\begin{array}{l}370.373, \\
2\end{array}$ & $\begin{array}{l}179.03 \\
8,9\end{array}$ & $-51,66$ \\
\hline LEBANON & $115.958,2$ & $69.980,6$ & $78.471,9$ & $76.910,8$ & $77.895,2$ & $-6,77$ & $18.363,1$ & $\begin{array}{l}25.592 \\
, 9\end{array}$ & 39,37 \\
\hline LIBYA & $48.738,5$ & $19.600,5$ & $576.506,6$ & $\begin{array}{l}437.892 \\
3\end{array}$ & $94.454,9$ & 55,73 & $14.534,4$ & $\begin{array}{l}8.064 \\
9\end{array}$ & $-44,51$ \\
\hline MAROKO & $89.605,1$ & $152.448,2$ & $277.851,6$ & $\mid \begin{array}{l}186.804 \\
5\end{array}$ & $\begin{array}{l}222.458 \\
2\end{array}$ & 22,41 & $51.346,0$ & $\begin{array}{l}86.603 \\
, 7\end{array}$ & 68,67 \\
\hline $\begin{array}{l}\text { MAURITANI } \\
\text { A }\end{array}$ & $13.380,6$ & $27.532,9$ & $72.223,7$ & $96.750,1$ & $\begin{array}{l}107.789 \\
5\end{array}$ & 72,11 & $28.658,5$ & $\begin{array}{l}15.176 \\
, 9\end{array}$ & $-47,04$ \\
\hline MESIR & $1.070 .049,2$ & $\begin{array}{l}1.588 .542, \\
0\end{array}$ & $\begin{array}{l}1.236 .622 \\
9\end{array}$ & $\mid \begin{array}{l}1.228 .65 \\
6,4\end{array}$ & $\begin{array}{l}1.486 .93 \\
6,1\end{array}$ & 4,09 & $\begin{array}{l}342.073, \\
0\end{array}$ & $\begin{array}{l}400.50 \\
6,7\end{array}$ & 17,08 \\
\hline OMAN & $319.121,4$ & $650.873,9$ & $464.026,5$ & $\begin{array}{l}462.339 \\
9\end{array}$ & $\begin{array}{l}438.301, \\
3\end{array}$ & 2,97 & $98.069,2$ & $\begin{array}{l}68.705 \\
, 0\end{array}$ & $-29,94$ \\
\hline PALESTINA & $3.451,2$ & 117,7 & $1.001,9$ & 553,8 & $1.028,6$ & $-8,35$ & 494,0 & 182,2 & $-63,12$ \\
\hline $\begin{array}{l}\text { PERSATUA } \\
\mathrm{N} \\
\text { EMIRAT } \\
\end{array}$ & $1.962 .786,0$ & $\begin{array}{l}2.531 .818, \\
5\end{array}$ & $\begin{array}{l}3.347 .337 \\
5\end{array}$ & $\begin{array}{l}3.398 .42 \\
4,7\end{array}$ & $\begin{array}{l}4.257 .46 \\
6,4\end{array}$ & 20,24 & $\begin{array}{l}1.094 .14 \\
8,5\end{array}$ & $\begin{array}{l}830.81 \\
6,4\end{array}$ & $-24,07$ \\
\hline QATAR & $649.316,9$ & $683.692,4$ & $\begin{array}{l}1.688 .672, \\
4\end{array}$ & $\begin{array}{l}1.576 .66 \\
3,4\end{array}$ & $\begin{array}{l}1.681 .65 \\
9,4\end{array}$ & 31,51 & $\begin{array}{l}514.564, \\
0\end{array}$ & $\begin{array}{l}236.96 \\
2,4\end{array}$ & $-53,95$ \\
\hline SUDAN & $200.613,4$ & $148.156,1$ & $84.417,6$ & $87.009,1$ & $75.127,7$ & $-22,09$ & $22.037,9$ & $\begin{array}{l}15.542 \\
, 3\end{array}$ & $-29,47$ \\
\hline SURIAH & $75.976,3$ & $77.522,9$ & $60.209,1$ & $34.555,9$ & $47.636,9$ & $-15,98$ & $8.778,9$ & $\begin{array}{l}10.934 \\
, 2\end{array}$ & 24,55 \\
\hline TUNISIA & $69.616,5$ & $99.127,7$ & $119.053,3$ & $\mid \begin{array}{l}101.991, \\
5\end{array}$ & $\begin{array}{l}104.210, \\
3\end{array}$ & 8,71 & $21.961,5$ & $\begin{array}{l}26.314 \\
, 6\end{array}$ & 19,82 \\
\hline YAMAN & $118.340,7$ & $99.187,3$ & $159.255,3$ & $\begin{array}{l}159.381 \\
3\end{array}$ & $\begin{array}{l}157.669, \\
3\end{array}$ & 11,05 & $46.667,8$ & $\begin{array}{l}37.553 \\
, 3\end{array}$ & $-19,53$ \\
\hline YORDANIA & $262.783,4$ & $409.491,4$ & $500.321,1$ & $\mid \begin{array}{l}475.123 \\
0\end{array}$ & $\begin{array}{l}305.191, \\
1\end{array}$ & 4,58 & $87.979,8$ & $\begin{array}{l}65.521 \\
, 2\end{array}$ & $-25,53$ \\
\hline
\end{tabular}


Berdasarkan data pada tabel 1.1 di atas, menunjukkan bahwa perkembangan perdagangan Indonesia ke negara-negara kawasan timur tengah, dari tahun 2010 sampai dengan tahun 2015 cendrung bergerak secara tidak seragam. Seperti, Arab Saudi, Maroko, Aljasair, Kwait, Persatuan Emirat Arab, dan Mauritania mengalami pergerakan secara fluktuatif dan cenderung meningkat, sedangkan negara-negara lainhya juga bergerak secara berfluktuatif dan cenderung menurun.

Upaya untuk menggenjot nilai ekspor, maka pemerintah Indonesia terus berusaha merealisasikan pencapaian target yang telah ditetapkan, salah satunya melalui pasar potensial peralatan kesehatan di kawasan Timur Tengah. Menurut Nus Nuzulia Ishak, tren peningkatan kinerja ekspor alkes di kawasan Timur Tengah dan Afrika juga tak lepas dari upaya promosi yang dilakukan secara aktif, konsisten, serta berkesinambungan sejak 2006 yang didukung oleh Asosiasi Produsen Alat Kesehatan Indonesia (ASPAKI). Peluang perdagangan antara Indonesia dengan negara-negara di kawasan Timur Tengah. dijawab oleh Kementerian Perdagangan melalui kegiatan promosi dalam pameran Arab Health Fair yang telah berlangsung pada tanggal 26 sampai 29 Januari 2015 di Dubai, Uni Emirate Arab (UEA). Pameran ini merupakan pameran produk kesehatan terbesar untuk kawasan Afrika dan Timur Tengah yang dikunjungi oleh para importir, wholesaler, dan distributor dari berbagai negara. Selain alkes, Indonesia masih memiliki banyak Produk unggulan lainnya, antara lain: produk-produk makanan, tekstil, bahan kimia, dan produk-pruduk pertanian, lemak nabati.

\section{B. Teori-Teori Perdagangan Internasional}

Perdagangan Internasional dapat diartikan sebagai transaksi dagang antara subyek ekonomi negara yang satu dengan subyek ekonomi negara yang lain, baik mengenai barang ataupun jasa-jasa. Adapun subyek ekonomi yang dimaksud adalah penduduk yang terdiri dari warga negara biasa, perusahaan ekspor, perusahaan impor, perusahaan industri, perusahaan negara ataupun departemen pemerintah yang dapat dilihat dari neraca perdagangan.

${ }^{5}$ Pradnyawati dan Ani Mulyati, "Indonesia Genjot Peluang Ekspor Peralatan Kesehatan ke Timur Tengah" Siaran Pers 23 Januari 2015 di Pusat Hubungan Masyarakat Kementerian Perdagangan di Jakarta.

${ }^{6}$ Nopirin, Ekonomi Internasional (Yogyakarta: BPFE, Juni 2010), h. 7. 
Perdagangan atau pertukaran dapat diartikan sebagai proses tukar menukar yang didasarkan atas kehendak sukarela dari masing-masing pihak. Masing-masing pihak harus mempunyai kebebasan untuk menentukan untung rugi dari pertukaran tersebut, dari sudut kepentingan masing-masing dan kemudian menetukan apakah ia mau melakukan pertukaran atau tidak. ${ }^{7}$ Pada dasarnya ada dua teori yang menerangkan tentang timbulnya perdagangan internasional.

\section{Teori Klasik}

\section{a. Merkantilis}

Para penganut merkantilisme berpendapat bahwa satu-satunya cara bagi suatu negara untuk menjadi kaya dan kuat adalah dengan melakukan sebanyak mungkin ekspor dan sedikit mungkin impor. Surplus ekspor yang dihasilkannya selanjutnya akan dibentuk dalam aliran emas lantakan, atau logam-logam mulia, khususnya emas dan perak. Semakin banyak emas dan perak yang dimiliki oleh suatu negara maka semakin kaya dan kuatlah negara tersebut. Dengan demikian, pemerintah harus menggunakan seluruh kekuatannya untuk mendorong ekspor, dan mengurangi impor (khususnya impor barang-barang mewah). Oleh karena itu, setiap negara tidak secara simultan dapat menghasilkan surplus ekspor, juga karena jumlah emas dan perak adalah tetap pada satu saat tertentu, maka sebuah negara hanya dapat memperoleh keuntungan dengan mengorbankan negara lain. ${ }^{8}$

Keinginan para merkantilis untuk mengakumulasi logam mulia ini sebetulnya cukup rasional, jika mengingat bahwa tujuan utama kaum merkantilis adalah untuk memperoleh sebanyak mungkin kekuasaan dan kekuatan negara. Dengan memiliki banyak emas dan kekuasaan, maka akan dapat mempertahankan angkatan bersenjata yang lebih besar dan lebih baik, sehingga dapat melakukan konsolidasi kekuatan di negaranya; peningkatan angkatan bersenjata dan angkatan laut juga memungkinkan sebuah negara untuk menaklukkan lebih banyak koloni. Selain itu, semakin banyak emas berarti semakin banyak uang dalam sirkulasi dan semakin besar aktivitas bisnis. Selanjutnya, dengan mendorong ekspor dan mengurangi impor pemerintah akan dapat

\footnotetext{
${ }^{7}$ Budiono, Teori Ekonomi Makro (Yogyakarta: UGM Press, 2000), h. 27.

${ }^{8}$ Nopirin, Ekonomi Internasional (Yogyakarta: BPFE, Juni 2010), h. 9.
} 
mendorong output dan kesempatan kerja nasional. ${ }^{9}$

b. Adam Smith

Adam Smith berpandangan bahwa sumber tunggal pendapatan adalah produksi hasil tenaga kerja serta sumber daya ekonomi. Dalam hal ini Adam Smith sependapat dengan doktrin merkantilis yang menyatakan bahwa kekayaan suatu negara dicapai dari surplus ekspor. Kekayaan akan bertambah sesuai dengan skill, serta efisiensi dengan tenaga kerja yang digunakan dan sesuai dengan persentase penduduk yang melakukan aktivitas tersebut. Menurut Smith, suatu negara akan mengekspor barang tertentu karena negara tersebut bisa menghasilkan barang dengan biaya yang secara mutlak lebih murah dari pada negara lain, yaitu karena memiliki keunggulan mutlak (Absolute Advantage) dalam produksi barang tersebut. Adapun keunggulan mutlak menurut Adam Smith merupakan kemampuan suatu negara untuk menghasilkan suatu barang dan jasa per unit dengan menggunakan sumber daya yang lebih sedikit dibanding kemampuan negara-negara lain.

Teori Absolute Advantage lebih mendasarkan pada besaran variabel riil bukan moneter sehingga sering dikenal dengan nama teori murni (pure theory) perdagangan internasional. Murni dalam arti bahwa teori ini memusatkan perhatiannya pada variabel riil seperti misalnya nilai suatu barang diukur dengan banyaknya tenaga kerja yang dipergunakan untuk menghasilkan barang. Makin banyak tenaga kerja yang digunakan akan makin tinggi nilai barang tersebut (labor theory of value).

Teori Absolute Advantage Adam Smith yang sederhana menggunakan teori nilai tenaga kerja. Teori nilai kerja ini bersifat sangat sederhana sebab menggunakan anggapan bahwa tenaga kerja itu sifatnya homogeny serta merupakan satu-satunya faktor produksi. Dalam kenyataannya tenaga kerja itu tidak homogen, faktor produksi tidak hanya satu dan mobilitas tenaga kerja tidak bebas. 11

\footnotetext{
${ }^{9}$ Nopirin, Ekonomi Internasional (Yogyakarta: BPFE, Juni 2010), h. 10

${ }^{10}$ Nopirin, Ekonomi Internasional (Yogyakarta: BPFE, Juni 2010), h. 11-12.

${ }^{11}$ Nopirin, Ekonomi Internasional (Yogyakarta: BPFE, Juni 2010), h. 11.
} 


\section{Teori Modern}

a. John Stuart Mill dan David Ricardo

Teori J.S.Mill menyatakan bahwa suatu negara akan menghasilkan dan kemudian mengekspor suatu barang yang memiliki comparative advantage terbesar dan mengimpor barang yang dimiliki comparative disadvantage (suatu barang yang dapat dihasilkan dengan lebih murah dan mengimpor barang yang kalau dihasilkan sendiri menghabiskan ongkos yang besar). Teori ini menyatakan bahwa nilai suatu barang ditentukan oleh banyaknya tenaga kerja yang dicurahkan untuk memproduksi barang tersebut. Kelebihan teori comparative advantage ini adalah dapat menerangkan berapa nilai tukar dan berapa keuntungan karena pertukaran di mana kedua hal ini tidak dapat diterangkan oleh teori absolute advantage. David Ricardo (1772-1823) seorang tokoh aliran klasik menyatakan bahwa nilai penukaran ada jikalau barang tersebut memiliki nilai kegunaan. Dengan demikian, sesuatu barang dapat ditukarkan bilamana barang tersebut dapat digunakan. Seseorang akan membuat sesuatu barang, karena barang itu memiliki nilai guna yang dibutuhkan oleh orang. Selanjutnya David Ricardo juga membuat perbedaan antara barang yang dapat dibuat dan atau diperbanyak sesuai dengan kemauan orang, di lain pihak ada barang yang sifatnya terbatas ataupun barang monopoli (misalnya lukisan dari pelukis ternama, barang kuno, hasil buah anggur yang hanya tumbuh di lereng gunung tertentu dan sebagainya). Dalam hal ini untuk barang yang sifatnya terbatas tersebut nilainya sangat subyektif dan relatif sesuai dengan kerelaan membayar dari para calon pembeli. Sedangkan untuk barang yang dapat ditambah produksinya sesuai dengan keinginan maka nilai penukarannya.

Berdasarkan atas pengorbanan yang diperlukan, David Ricardo mengemukakan bahwa berbagai kesulitan yang timbul dari ajaran nilai kerja:

1) Perlu diperhatikan adanya kualitas kerja, ada kualitas kerja terdidik dan tidak terdidik, kualitas kerja keahlian dan lain sebagainya. Aliran yang klasik dalam hal ini tidak

${ }^{12}$ Branson, Macroekonomics Model with Portofolio Balance in Open Economy (Stockholm: Institut for Internasional Economic Studies, 1972), h. 27-21.

${ }^{13}$ Branson, Macroekonomics Model with Portofolio Balance In Open Economy (Stockholm: Institut for Internasional Economic Studies, 1972), h. 27-21. 
memperhitungkan jam kerja yang dipergunakan untuk pembuatan barang, tetapi jumlah jam kerja yang biasa dan semestinya diperlukan untuk memproduksi barang. Dari situ maka Carey kemudian mengganti ajaran nilai kerja dengan teori biaya reproduksi.

2) Kesulitan yang terdapat dalam nilai kerja itu bahwa selain kerja masih banyak lagi jasa produktif yang ikut membantu pembuatan barang itu, harus dihindarkan. Selanjutnya David Ricardo menyatakan bahwa perbandingan antara kerja dan modal yang dipergunakan dalam produksi boleh dikarakan tetap besarnya dan hanya sedikit sekali perubahan. Atas dasar nilai kerja, dibedakan di samping harga alami (natural price) ada pula harga pasaran (market price).

Teori perdagangan internasional diketengahkan oleh David Ricardo yang mulai dengan anggapan bahwa lalu lintas pertukaran internasional hanya berlaku antara dua negara yang di antara mereka tidak ada tembok pabean, serta kedua negara tersebut hanya beredar uang emas. Ricardo memanfaatkan hukum pemasaran bersama-sama dengan teori kuantitas uang untuk mengembangkan teori perdagangan internasional. Walaupun suatu negara memiliki keunggulan absolut, akan tetapi apabila dilakukan perdagangan tetap akan menguntungkan bagi kedua negara yang melakukan perdagangan.

Teori perdagangan telah mengubah dunia menuju globalisasi dengan lebih cepat. Kalau dahulu negara yang memiliki keunggulan absolut enggan untuk melakukan perdagangan, berkat "law of comparative costs" dari Ricardo, Inggris mulai kembali membuka perdagangannya dengan negara lain. Pemikiran kaum klasik telah mendorong diadakannya perjanjian perdagangan bebas antara beberapa negara. Teori comparative advantage telah berkembang menjadi dynamic comparative advantage yang menyatakan bahwa keunggulan komparatif dapat diciptakan. Oleh karena itu, penguasaan teknologi dan kerja keras menjadi faktor keberhasilan suatu negara. Bagi negara yang menguasai teknologi akan semakin diuntungkan dengan adanya perdagangan bebas ini, sedangkan negara yang hanya mengandalkan kepada kekayaan alam akan kalah dalam persaingan

${ }^{14}$ Chacholiades Miltiades, Principles of Internassional Econimics (New York: McGraw, Hill Book Company, 1981), h. 25-26. 
internasional. $^{15}$

Terdapat beberapa asumsi yang dibangun dalam teori Comparative Advantage, sebagai berikut:

a. Cost Comparative Advantage (Labor Efficiency)

Menurut teori cost comparative advantage (labor efficiency), suatu negara akan memperoleh manfaat dari perdagangan internasional jika melakukan spesialisasi produksi dan mengekspor barang di mana negara tersebut dapat berproduksi relatif lebih efisien serta mengimpor barang di mana negara tersebut berproduksi relatif kurang efisien. Berdasarkan contoh hipotesis di bawah ini maka dapat dikatakan bahwa teori comparative advantage dari David Ricardo adalah cost comparative advantage.

\section{b. Production Comperative Advantage (Labor Productifity)}

Suatu negara akan memperoleh manfaat dari perdagangan internasional jika melakukan spesialisasi produksi dan mengekspor barang di mana negara tersebut dapat berproduksi relatif lebih produktif serta melakukan aktivitas impor barang ke suatu negara, di mana negara tersebut berproduksi relatif kurang produktif. Walaupun Indonesia memiliki keunggulan absolut dibandingkan Cina untuk kedua produk, sebetulnya perdagangan internasional akan tetap dapat terjadi dan menguntungkan keduanya melalui spesialisasi di masing-masing negara yang memiliki labor productivity. Kelemahan teori klasik Comparative Advantage tidak dapat menjelaskan mengapa terdapat perbedaan fungsi produksi antara dua negara. Sedangkan kelebihannya adalah perdagangan internasional antara dua negara tetap dapat terjadi walaupun hanya satu negara yang memiliki keunggulan absolut asalkan masing-masing dari negara tersebut memiliki perbedaan dalam Cost Comparative Advantage atau Production Comparative Advantage. Teori ini mencoba melihat kuntungan atau kerugian dalam perbandingan relatif. Teori ini berlandaskan pada asumsi: Labor Theory of Value, yaitu bahwa nilai suatu barang ditentukan oleh jumlah tenaga kerja yang dipergunakan untuk menghasilkan barang tersebut, di mana nilai barang yang ditukar seimbang dengan jumlah tenaga kerja yang dipergunakan untuk

${ }^{15}$ Chacholiades Miltiades, Principles of Internassional Econimics (New York: McGraw, Hill Book Company, 1981), h. 27. 
memproduksinya. 16

b. Teori Heckscher-Ohlin (H-O)

Teori Heckscher-Ohlin (H-O) menjelaskan beberapa pola perdagangan dengan baik, negara-negara cenderung untuk mengekspor barang-barang yang menggunakan faktor produksi yang relatif melimpah secara intensif. Menurut Heckscher-Ohlin, suatu negara akan melakukan perdagangan dengan negara lain disebabkan negara tersebut memiliki keunggulan komparatif, yaitu keunggulan dalam teknologi dan keunggulan faktor produksi. Basis dari keunggulan komparatif adalah:

1) Faktor endowment, yaitu kepemilikan faktor-faktor produksi di dalam suatu negara.

2) Faktor intensity, yaitu teknologi yang digunakan di dalam proses produksi, apakah labor intensity atau capital intensity.

Teori modern Heckescher-Ohlin atau teori $\mathrm{H}-\mathrm{O}$ menggunakan dua kurva pertama adalah kurva isocost, yaitu kurva yang menggambarkan total biaya produksi yang sama. Dan kurva isoquant yaitu kurva yang menggambarkan total kuantitas produk yang sama. Menurut teori ekonomi mikro kurva isocost akan bersinggungan dengan kurva isoquant pada suatu titik optimal. Jadi dengan biaya tertentu akan diperoleh produk yang maksimal atau dengan biaya minimal akan diperoleh sejumlah produk tertentu. Analisis hipotesis H-O dikatakan berikut:

1) Harga atau biaya produksi suatu barang akan ditentukan oleh jumlah atau proporsi faktor produksi yang dimiliki masing-masing negara.

2) Comparative Advantage dari suatu jenis produk yang dimiliki masingmasing negara akan ditentukan oleh struktur dan proporsi faktor produksi yang dimilikinya.

3) Masing-masing negara akan cenderung melakukan spesialisasi produksi dan mengekspor barang tertentu karena negara tersebut memiliki faktor produksi yang relatif banyak dan murah untuk memproduksinya.

4) Sebaliknya masing-masing negara akan mengimpor barang-barang

\footnotetext{
${ }^{16}$ Branson W., Macroecoomics Model with Portofolio Balance in Open Ekonomy (Stockholm: Institute for International Economic Studies, t.th.), h. 27-29.

${ }^{17}$ Nopirin, Ekonomi Internasional (Yogyakarta: BPFE, Juni 2010), h. 20-21.
} 
tertentu karena negara tersebut memilki faktor produksi yang relatif sedikit dan mahal untuk memproduksinya.

5) Kelemahan dari teori $\mathrm{H}-\mathrm{O}$ yaitu jika jumlah atau proporsi faktor produksi yang dimiliki masing-masing negara relatif sama, maka harga barang yang sejenis akan sama pula sehingga perdagangan internasional tidak akan terjadi.

Teori perdagangan internasional modern dimulai ketika ekonom Swedia, yaitu Eli Hecskher (1919) dan Bertil Ohlin (1933) mengemukakan penjelasan mengenai perdagangan internasional yang belum mampu dijelaskan dalam teori keunggulan komparatif. Sebelum masuk ke dalam pembahasan teori $\mathrm{H}-\mathrm{O}$. Tulisan ini sedikit akan mengemukakan kelemahan teori klasik yang mendorong munculnya teori $\mathrm{H}-\mathrm{O}$. Teori klasik comparative advantage menjelaskan bahwa perdagangan internasional dapat terjadi karena adanya perbedaan dalam productivity of labor (faktor produksi yang secara eksplisit dinyatakan) antarnegara. Namun teori ini tidak memberikan penjelasan mengenai penyebab perbedaan produktivitas tersebut. Teori $\mathrm{H}-\mathrm{O}$ kemudian mencoba memberikan penjelasan mengenai penyebab terjadinya perbedaan produktivitas tersebut. Teori $\mathrm{H}-\mathrm{O}$ menyatakan penyebab perbedaan produktivitas karena adanya jumlah atau proporsi faktor produksi yang dimiliki (endowment factors) oleh masing-masing negara, sehingga selanjutnya menyebabkan terjadinya perbedaan harga barang yang dihasilkan. Oleh karena itu, teori modern $\mathrm{H}-\mathrm{O}$ ini dikenal sebagai "The Proportional Factor Theory". Selanjutnya negara-negara yang memiliki faktor produksi relatif banyak atau murah dalam memproduksinya akan melakukan spesialisasi produksi untuk kemudian mengekspor barangnya. Sebaliknya, mengimpor barang tertentu jika negara masing-masing negara akan produksi yang relatif langka atau mahal dalam memproduksinya.

Sejalan dengan uraian tersebut $\mathrm{di}$ atas, terdapat beberapa hipotesis yang dibangun dalam teori $\mathrm{H}-\mathrm{O}$, antara lain:

1. Produksi barang ekspor di tiap negara naik, sedangkan produksi barang impor di tiap negara turun.

2. Harga atau biaya produksi suatu barang akan ditentukan oleh

${ }^{18}$ Grubel H.C., Internasional Economics (Homewood, Illionis: Richard D. Irwin, Inc, 1977), h. 12-13 
jumlah atau proporsi faktor produksi yang dimiliki masing-masing negara.

3. Harga labor di kedua negara cenderung sama, harga barang A di kedua negara cenderung sama demikian pula harga barang B di kedua negara cenderumg sama.

\section{Pentingnya Perdagangan Internasional}

Liberalisasi perdagangan akan memberikan manfaat bagi negaranegara yang terlibat dalam perdagangan, yaitu: 1) Memperoleh devisa yang dapat digunakan sebagai alat tukar internasional, alat pembayaran luar negeri, dan stabilitas mata uang suatu Negara, devisa merupakan salah satu instrument yang digunakan untuk mengelolah nilai tukar mata uang, karena apabila nilai tukar mata uang suatu Negara sedang terdepresiasi secara drastis, maka lembaga otoritas akan melepas cadangan devisa agar nilai tukar uang domestik dapat terapresiasi; 2) Memperluas kesempatan kerja, karena perdagangan internasional akan mendorong meningkatnya arus barang, modal, dan teknoligi sehingga dapat memicu meningkatnya aktivitas ekonomi suatu Negara. Ketersediaan modal dan teknologi yang cukup memadai, maka akan meningkatnya aktivitas produksi, dan diikuti pula meningkatnya aktivitas perdagangan; 3) Mendorong terjadinya kestabilan harga, karena meningkatmya persaingan perdagangan di antara industry, maka akan berimplikasi pada persaingan harga, dan konsumen akan memilih produk yang harganya lebih rendah dengan kualitas yang relative sama atau bahkan lebih bagus; 4) Meningkatkan kualitas konsumsi masyarakat dengan meningkatya jumlah barang yang ditawarkan, dan diikuti pula dengan meningkatnya kualitas barang yang ditawarkan. Selain itu, masyarakat akan memperoleh barang yang tidak dapat diproduksi di negeri sendiri; 5) Mempercepat alih teknologi yang didorong oleh persaingan yang semakin ketat, karena teknologi yang baik akan menghasilkan out put yang baik pula dengan biaya yang lebih efisien serta kapasistas produksi yang lebih tinggi. Di samping itu, kebijakan perdagangan yang semakin terbuka akan memudahkan pula dilakukannya transfer teknologi antar Negara yang terus mengalami perkembangan; 6) Memperoleh keuntungan dari spesialisasi, karena perdagangan antar negara dapat berjalan dengan baik apabila oleh masing-masing Negara menghasilkan produk yang cenderung berbeda. Disamping itu, untuk mencapai kualitas produk yang lebih baik, sehingga setiap negara 
diharapkan unuk melakukan spesialisasi: 7) Terakhir, Memperluas pasar, sehingga kesempatan untuk mendistribusikan produk semakin tinggi, dan begitu pula kesempatan untuk memilih berbagai jenis produk semakin banyak dengan berbagai tingkat harga. 19

\section{Potensi dan Peluang Perdagangan antara Indonesia dengan Negara- Negara di Timur Tengah}

Pada penelitian ini ditemukan bahwa terdapat beberapa potensi yang dapat mendorong perdagangan antara Indonesia dengan negaranegara di kawasan timur tengah, antara lain: 1) Produk-produk yang dihasilkan di Indonesia cukup beragam dan cenderung berbeda dengan produk yang dihasilkan di negara-negara timur tengah. Indonesia memiliki banyak produk unggulan yang cukup digemari di negara UEA, yaitu: alat kesehatan, tekstil, dan lemak nabati dan hewani, elektronik, karet dan produk karet, otomotif, udang, dan alas kaki. Selain itu, terdapat pula berbagai komoditi pertanian yang cenderung berbeda dengan produk pertanian yang dihasilkan oleh negara-negara timur tengah. Indonesia sebagai negara yang memiliki tanah subur dan didukung oleh musin yang teratur, maka Indonsia banyak menghasilkan produk-produk pertanian dengan kualitas yang cukup bagus, seperti kakao, kopi, sawit dan produk sawit, serta produk hasil hutan. ${ }^{20}$. Sektor pertanian memiliki komposisi yang cukup dominan dalam struktur ekonomi nasional. Berbeda dengan negara-negara kawasan Timur Tengah, karakter iklim di kawasan timur tengah cenderung panas dengan suhu udara yang cukup tinggi, serta cura hujan yang kurang dan cenderung tidak teratur, akibatnya sangat terbatas untuk melakukan aktivitas bercocok tanam, sehingga tidak dapat menghasilkan komoditi pertanian. Adapun produk pertanian yang menjadi produk unggulan di negara timur tengah, yaitu: gandum dan kurma. Walaupun di negaranegara kawasan timur tengah tidak banyak menghasilkan komoditi pertanian, akan tetapi di negara-negara kawasan timur tengah memiliki produksi minyak bumi yang sangat melimpah, dan selama ini merupakan produk unggulan. Dengan demikian, adanya kecenderungan produk yang dihasilkan cenderung berbeda, maka sangat mendukung untuk dilakukan

${ }^{19}$ Grubel H.C., Internasional Economics (Homewood, Illionis; Richard D. Irwin, Inc., 1977), h. 14-16

${ }^{20}$ Kementerian Perdagangan, Statistik Perdagangan, Ringkasan dan Evaluasi Perdagangan Luar Negeri, Volume I, 2013, h. 6. 
hubungan perdagangan antara Indonesia dengan negara-negara di kawasan timur tengah; 2) Pertumbuhan ekonomi di negara-negara timur tengah relatif lebih stabil dan bahkan cenderung meningkat dalam beberapa tahun terakhir walaupun mereka sedang dilanda konlik sosial yang berkepanjangan. Kondisi tersebut, berbeda dengan yang dialami oleh negara-negara lain, seperti negara-negara di benua Eropa maupun Amerika yang sampai saat ini ekonominya masih belum stabil. Kondisi tersebut, juga ikut dirasakan oleh negara-negara di asia, seperti Cina, Malaysia, singapura, dan termasuk Indonesia. Walaupun demikian, dalam sepuluh tahun terakhir perekonomian Indonesia cenderung mengalami pertumbuhan, walaupun dalam satun tahun terakhir ini hanya tumbuh sekitar 4,5 persen; 3) Indonesia memilikin komoditi ekspor yang cukup beragam dengan keunggulan komparatif yang cukup kuat, baik berupa produk pertanian maupun hasil-hasil industri; 4) Pertumbuhan modal asing di negara-negara timur tengah cenderung meningkat dalam lima tahun terakhir, yaitu pada kisaran 3 sampai 4 persen pada setiap tahunnya. Begitu pula dengan Indonesia, pertumbuhan modal asing cenderung meningkat dalam periode waktu yang sama, dan bahkan pada tahun 2015 Pertumbuhan modal asing mencapai 20 persen.

Selain memiliki potensi yang cukup tinggi juga terdapat peluang perdagangan yang cukup baik antara Indonesia dengan negara-negara di kawasan timur tengah, yaitu: 1) Adanya perubahan kebijakan ekonomi di yang berorientasi pada ekonomi pasar, sehingga memungkinkan bagi negara-negara lainnya untuk ikut berpartisipasi dalam meramaikan pasar di kawasan Timur Tengah. Di samping itu, pemerintah Indonesia terus melakukan penetrasi pasar, baik di kawasan Timur Tengah maupun negara-negara di belahan dunia terus dikembangkan. Integrasi pasar yang luas akan memberikan banyak manfaat, karena kita dapat memmilih pasar yang lebih efisien, sehingga akan mendapatkan keuntungan yang optimal; 2) Hubungan diplomasi bilateral antara Indonesia dengan negara-negara di Timur Tengah telah terjalin dengan baik dan juga sudah berlangsung dalam jangka waktu yang sudah cukup lama. Disamping itu, negara yang paling pertama mengakui kedaulatan Indonesia adalah Mesir; 3) Persamaan keyakinan, sehingga memungkinkan mengaplikasikan prinsip-prinsip ekonomi syariah yang juga memegang

${ }^{21}$ Data Pusat Kebijakan Perdagangan Luar Negeri, Badan Pengkajian dan Pengembangan Kebijakan Perdagangan. 
peran penting untuk meningkatkan kaepercayaan pelaku bisnis; 4) Adanya wacana akan dilakukannya perdagangan bebas antara Indonesia dengan Maroko dan Turki; 5) Daya saing produk Indonesia yang cukup tinggi, sehingga cukup diminati oleh masyarakat di negara-negara kawasan Timur Tengah, khusnya alat kesehatan, garmen, dan lemak hewani maupun nabati.

\section{E. Kendala yang Dihadapi oleh Perdagangan antara Indonesia dengan Negara-Negara Kawasan Timur Tengah}

Selain potensi dan peluang, terdapat pula berbgai kendala yang dihadapi dalam melakukan perdagangan antara Indonesia dengan Negara-negara di kawasan Timur Tengah, yaitu: 1) Diasosiasikan dengan jarak yang panjang, sehingga akan berkonsekuensi pada biaya yang tinggi; 2) Tarif bea masuk yang tinggi, sehingga akan berimplikasi pada peningkatan harga jual prodak, karena tambahan biaya akan dikonversikan ke dalam harga jual produk, akibatnya harga produk akan meningat, sehingga akan berpengaruh terhadap daya saing; 3) Iklim politik yang kurang stabil, seperti kita ketahui bahwa negara-negara di kawasan timur tengah sedang dilandah konflik sosial yang berkepanjangan. Aktivitas politik cenderung ekspresikan dalam bentuk kekerasan fisik, sehingga akan berdampak luas terhadap kehidupan masyarakat, karena masyarakat tidak dapat melakukan aktivitasnya dengan baik, termasuk aktivitas ekonomi, karena mereka dilanda ketakutan dan kecemasan. Dengan demikian, kondisi tersebut akan semakin memperburuk kondisi perekonomian; 4) Dukungan dari sektor lembaga keuangan sangat dibutuhkan karena berkaitan dengan kebutuhan modal kerja. Di samping itu, aktivitas pembayaran terhadap perdagangan internasional harus melalui lembaga keuangan antar kedua negara yang sedang berdagang. Oleh karenya, kerja sama diantara lembaga keuagan dari kedua negara yang sedang berdagang sangat diperlukan; 5) Sertifikasi halal merupakan sesuatu yang urgen, karena masyarakat di negara-negara kawasan Timur Tengah mayoritas beragama muslim, sehinga dibutuhkan sertfikasi halal yang diakui oleh negara-negara di kawasan timur tengah. Saat ini, belum ada lembaga resmi yang mendapatkan legitimasi secara internasional untuk melakukan sertisifikasi terhadap berbagai produk ekspor. 


\section{F. Langkah-Langkah Strategis dalam Mendorong Perdagangan antara Indonesia dengan Negara-Negara di Kawasan Timur Tengah}

Ada beberapa langkah strategis yang dapat ditempuh untuk mendorong meningkatnya perdagangan antara Indonesia dengan negaranegara di Kawasan Timur Tengah, yaitu: 1) Membangun kepercayaan adalah sesuatu yang mutlak harus dilakukan dalam rangka untuk meningkatkan sinergisitas dengan negara-negara di kawasan Timur Tengah yang dibangun melalui hubungan diplomasi antar kedua Negara; 2) Diversifikasi produk melalaui Identifikasi potensi perdagangan dalam rangka untuk meningkatkan efektifitas perdagangan dengan memfokuskan pada produk-produk yang dianggap memiiki potensi yang baik untuk di ekspor ke kawasan negara-negara Timur Tengah, seperti: alat kesehatan, lemak hewani dan nabati, tekstil atau garmen, dan produk-produk unggulan lainnya; 3) Mendorong terealisasinya perjanjian kerja sama ekonomi antara Indonesia dengan negara-negara kawasan Timur Tengah yang harus dibangun secara berkelanjutan; 4) Mendorong hubungan people to people untuk memperluas jaringan dengan cara meningkatkan event-event internasional dengan melibatkan masyarakat Indonesia dengan masyarakat di negara-negara kawasan Timur Tengah. Kegiatan tersebut dimaksudkan untuk meningkatkan keterlibatan masyarakat secara luas untuk memperkenalkan potensi-potensi yang ada di negara masing-masing; 5) Saatnya Indonesia memanfaatkan jaringan diaspora yang dilakukan secara terorganisir oleh pemerintah. Kegiatan ini dimaksudkan untuk mendorong peran serta masyarakat, khususnya bagi mereka yang berada di kawasan negara-negara kawasan Timur Tengah, agar mereka secara aktif ikut serta mempromosikan potensipotensi ekonomi yang ada di Indonesia, sehingga potensi tersebut dapat di kenal luas oleh masyarakat Timur Tengah; 6) Peran aktif pemerintah Indonesia untuk menjadi mediator sangat diharapkan. Di samping itu, diharapkan pula kesediaan pemerintah untuk menyiapkan perangkatperangkat pendukungnya agar dapat memudahan dalam menjalankan aktivitas perdagagan dengan negara-negara di kawasan Timur Tengah; 7) Meminimalisir berbagai barrier, baik yang berupa kebijakan fiskal maupun non fiskal, seperti tarif bea masuk barang, penetapan kuota, persyaratan perdagangan maupun mekanisme pedagangan yang terkadang berbelit-beit, sehingga akan menyulitkan bagi para pelaku Bisnis; 8) Mendorong terealisasinya perjanjian kerjasama ekonomi antara 
Indonesia dengan negara-negara Timur Tengah yang mengarah pada perdagangan bebas.

\section{G. Kesimpulan}

Berdasarkan uraian di atas, maka kesimpulan penelitian dapat dirumuskan sebagai berikut:

Hubungan perdagangan antara Indonesia dengan negara-negara di kawasan Timur Tengah memiliki potensi yang cukup baik dengan meilihat beberapa aspek, yaitu: Pertama, produk-produk yang dihasilkan di Indonesia beragam dan cenderung berbeda dengan produk yang dihasilkan di negara-negara Timur Tengah. Kedua, Pertumbuhan ekonomi di negara-negara Timur Tengah relatif stabil dan bahkan cenderung meningkat dalam beberapa tahun terakhir. Ketiga, Indonesia memilikin komoditi ekspor yang cukup beragam dengan keunggulan komparatif yang cukup kuat, baik berupa produk pertanian maupun hasilhasil industri. Keempat, pertumbuhan modal asing di negara-negara Timur Tengah cenderung meningkat dalam lima tahun terakhir, yakni pada kisaran 3 sampai 4 persen pada setiap tahunnya. Begitu pula dengan Indonesia, pertumbuhan modal asing cenderung meningkat dalam periode waktu yang sama.

Selain memiliki potensi yang cukup baik, juga terdapat berbagai peluang perdagangan antara Indonesia dengan negara-negara di kawasan Timur Tengah, yaitu: Pertama, Adanya perubahan kebijakan ekonomi di yang berorientasi pada ekonomi pasar; Kedua, hubungan diplomasi bilateral antara Indonesia dengan negara-negara di kawasan timur tengah telah terjalin dengan baik, serta sudah berlangsung dalam jangka yang sudah cukup lama; Ketiga, persamaan keyakinan, sehingga memungkinkan mengaplikasikan prinsip-prinsip ekonomi syariah yang dapat memegang peranan penting dalam meningkatkan kaepercayaan pelaku bisnis. Ketiga, adanya wacana akan dilakukannya perdangan bebas antara Indonesia dengan Maroko dan Turki; dan Keempat, daya saing produk Indonesia yang cukup tinggi, terutama produk-produk alat kesehatan, garmen atau tekstil, dan lemak nabati.

Selain memiliki potensi maupun peluang, terdapat pula berbagai kendala yang dihadapi dalam membangun hubungan perdagangan antara Indonesia dengan negara-negara di kawasan Timur Tengah, antara lain: tarif bea masuk yang tinggi, Iklim politik yang kurang stabil, terbatasnya dukungan dari sektor lembaga keuangan sebagai lembaga penunjang dalam melakukan aktivitas pembayaran terhadap perdagangan 
internasional, dan belum ada lembaga resmi yang mendapatkan legitimasi secara internasional untuk melakukan sertisifikasi terhadap berbagai produk ekspor.

\section{H. Saran}

Berdasarkan uraian latar belakang, kesimpulan, dan pembahasan, maka saran penelitian dapat dirumuskan sebagai berikut:

Mendorong terealisasinya perjanjian kerjasama ekonomi antara Indonesia dengan negara-negara Timur Tengah, maka disarankan kepada pemerintah Indonesia untuk meningkatkan hubungan secara berkelanjutan, baik antar lembaga pemerintahan maupun hubungan antar people to people melalui event-event Internasional dengan melibatkan masyarakat Indonesia dengan masyarakat di negara-negara kawasan Timur Tengah.

Pemerintah Indonesia disarankan untuk memanfaatkan jaringan diaspora dalam rangka untuk membangun semangat nasionalisme masyarakat Indonesia yang berada di luar negeri dengan melalui berbagai kegiatan yang dilakukan secara terorganisir dan berkelanjutan, agar memiliki kepedulian yang tinggi terhadap negaranya dengan secara aktif mempromosikan potensi-potensi ekonomi yang ada di Indonesia.

Selanjutnya, untuk terus mendorong meningkatnya hubungan perdagangan antara Indonesia dengan Negara-negara di kawasan Timur Tengah, maka pada penelitian ini disarankan untuk meminimalisir berbagai barrier, baik yang berupa kebijakan fiskal maupun non fiskal, seperti tarif bea masuk barang, penetapan kuota, dan persyaratan perdagangan yang dianggap cenderung menyulitkan maupun mekanisme pedagangan yang terkadang berbelit-beit, sehingga cenderung menyusahkan bagi para pelaku bisnis. Terakhir, mendorong terealisasinya perjanjian kerja sama ekonomi antara Indonesia dengan negara-negara di kawasan Timur Tengah.

\section{DAFTAR PUSTAKA}

Branson. 1972. Macroekonomics Model with Portofolio Balance In Open Economy. Stockholm: Institut for Internasional Economic Studies.

Budiono. 2000. Teori Ekonomi Makro. Yogyakarta: UGM Press.

Buletin Ilmiah Litbang Perdagangan, Vol. 5 No. 1 Juli 2011 
Volume. 12, Nomor 1, Juni 2016

Halaman 60-80
Potensi, Peluang, Dan Tantangan Perdagangan Antara Indonesia Dengan Negara-Negara Di Kawasan Timur Tengah

Grubel H.C. 1977. Internasional Economics. Homewood, Illionis:Richard D. Irwin, Inc.

Kementerian Perdagangan. 2013. Ringkasan dan Evaluasi Perdagangan Luar Negeri, Volume I.

Kementerian Perdagangan. 2013. Statistik Perdagangan, Ringkasan dan Evaluasi Perdagangan Luar Negeri, Volume I.

Miltiades, Chacholiades. 1981. Principles of Internassional Econimics. New York: McGraw, Hill Book Company.

Nopirin. 2010. Ekonomi Internasional. Yogyakarta: BPFE, Juni. Pusat Kebijakan Perdagangan Luar Negeri, Badan Pengkajian dan

Pengembangan Kebijakan Perdagangan. Pradnyawati dan Ani Mulyati, 2015. "Indonesia Genjot Peluang

Ekspor Peralatan Kesehatan ke Timur Tengah" Siaran Pers di Pusat Hubungan Masyarakat Kementerian Perdagangan di Jakarta.

Oktaviani, Rina. 2008. Jurnal Agro Ekonomi, Volume 26 No. 2 ktober. 